\title{
Recent and future of cement and concrete industries- a root of our development
}

\author{
Ts.Erdenebat $^{1}$, J.Otgonlham ${ }^{1}$, E.Oyunzul ${ }^{1}$, R.Sanjaasuren ${ }^{1}$ \\ ${ }^{1}$ Centre for Chemistry and Technology of New Materials, \\ School of Chemistry and Chemical Engineering, National University of Mongolia
}

\begin{abstract}
This paper considers that cement and concrete industry is contributing to our country development positively, and cement and concrete industry also can be reduced environmental pressure by;- Continuously reducing the $\mathrm{CO}_{2}$ emission from cement production by increased use of biofuels and alternative raw materials as well as introducing modified low energy clinker types and cement with reduced clinker content or geopolymer cement and a new type concrete.

- Exploiting the potential of waste bricks, cement and concrete recycling to decrease the emission of $\mathrm{CO}_{2}$.

- Exploiting the thermal mass of concrete to create energy optimized solutions for heating and cooling residential and office buildings.
\end{abstract}

Keywords: climate change, $\mathrm{CO}_{2}$ emission, brick, block, cementitious materials, cement and concrete, building and policymakers

\section{Introduction}

T eading branches of industry at present in Mongolia are:

- Coal mining for electric power station,

- Ore dressing plant (copper, molybdenum, fluorspar, gold etc.),

- Manufacture of building materials (cement, concrete, brick, lime etc.),

- Manufacture of food products

- Manufacture of light industry (clothing, cashmere, wool, leather and other products).

Cement is an essential material in today's society because, it major constituent of concrete which act, as a fundamental element of any housing, commercial or infrastructure development. But the cost to manufacture cement is expected to increase from year to year, because of increasing energy prize.

Therefore scientists are attempting to prepare OPC and other binding materials at lower cost by using agricultural and industrial wastes during clinkerization and by making blended cements.

The measures are changed to decrease the cost of production, conserve mineral resources and protect the environment by beneficial disposal of wastes. So blended cements are usually blends of Portland cement clinker with other finely ground materials (known as mineral admixtures) that take part in the hydration reactions and thereby make a substantial contribution to the hydration products.

In last 10 years at the Centre for Chemistry and Technology of New Materials, National University of Mongolia, our researchers have 
focused on obtaining of a new crystallizing component such as mineral admixtures, from natural aluminosilicate as kaoline, basalts and zeolites for blended cement additive materials.

It was established that cement compressive strength increased by $100-250 \mathrm{~kg} / \mathrm{cm}^{2}$ when doped $5-10 \%$ of crystallizing component to the cement weight [3-6]. Nowadays large numbers of blended cements are studied by re-using a variety of waste materials because of construction material demand due to increased infrastructure development in Ulaanbaatar city and other places.

In recent 2 years research capacity of the Centre for Chemistry and Technology of New Materials, National University of Mongolia is focused to substitute some part of cement powder with waste alumosilicate material as crystallizing component that has also started in high developed countries since 2000 .

\section{Experimental}

Recent and future tendency of cement and concrete industries in the world. Batelle offered the following vision[?]: By 2020 cement companies will integrated in sustainable development of their global operations. They will known as innovators in industrial ecology and carbon dioxide management, are regarded as attractive employers, and have established relationships of trust with the communities in which they operate. The actions leading to this integrated sustainable development were suggested to be:

1) Resource productivity - The industry makes productive use of specific materials that otherwise would be discarded as waste, and applies state-of-the-art technologies and operating practices to cost-effectively improve its efficiency in energy and material consumption.

2) Climate protection. The industry has implemented practical, technological, operational, and market-based strategies to significantly reduce emissions of $\mathrm{CO} 2$ and is technologically positioned for even greater reductions in the future.
3) Emission reduction . The industry has continuously improved its environmental practices and controls to achieve a minimal release of wastes or emissions that could adversely affect human health, ecosystems, and aesthetics.

4) Ecological stewardship . The industry develops, operates, and retires its plants and quarries in a manner that minimises adverse impacts on the environment, including biodiversity and aesthetics, and protects and restores potentially impacted ecosystems. In doing so, it has earned support and recognition in the eyes of the community and regulators.

5) Employee well-being . The industry builds and operates its facilities in a way that fosters employee satisfaction and productivity, provides fair wages and benefits, and is a safe, clean, healthy and desirable place to work.

6) Community well-being . The industry is well understood and respected by the communities in which it operates because companies and plants make efforts to understand community needs and to help find ways to meet those needs. The industry has implemented measures to address nuisance disturbances associated with quarrying, transportation, and plant operations.

7) Regional development . The industry and its associated value chain are viewed as positive contributors to local and regional economies and countries welcome the growth and prosperity of the industry because it is considered a critical component of infrastructure development and maintenance.

8) Shareholder value creation. The industry provides competitive returns to investors and is able to readily secure capital resources. Cement companies that have adopted SD practices are desirable investments for sustainable development index funds, and have increased their profitability and market share.

The Batelle report went further to recommend sustainable development goals and key performance indicators for cement manufacturers using the same list of actions given above. 


\section{Conclusions}

Recommended sustainable development goalsand Key Performance Indicators /KPI/:

\begin{tabular}{|c|c|c|}
\hline Issues & Goal & KPI \\
\hline $\begin{array}{l}\text { Resource } \\
\text { productivity }\end{array}$ & $\begin{array}{l}\text { Conserve } \\
\text { resources } \\
\text { by } \\
\text { using less } \\
\text { energy and } \\
\text { recycling } \\
\text { wastes }\end{array}$ & 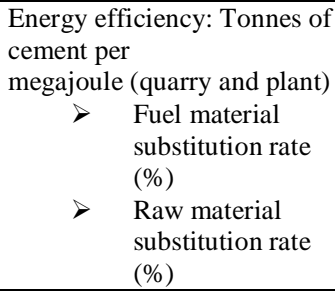 \\
\hline $\begin{array}{l}\text { Climate } \\
\text { protection }\end{array}$ & $\begin{array}{l}\text { Reduce } \\
\text { greenhouse } \\
\text { gas } \\
\text { emissions }\end{array}$ & $\begin{array}{l}\text { Net } \mathrm{CO}_{2}(\mathrm{~kg}) \text { emissions per } \\
\text { tonne of cement }\end{array}$ \\
\hline $\begin{array}{l}\text { Emission } \\
\text { reduction }\end{array}$ & $\begin{array}{l}\text { Reduce } \\
\text { environme } \\
\text { ntal } \\
\text { waste } \\
\text { streams }\end{array}$ & $\begin{array}{l}\text { Waste (non-product output) } \\
\text { produced (kg) per } \\
\text { tonne of cement (can include } \\
\text { airborne } \\
\text { emissions waterborne } \\
\text { effluents, fugitive dust, } \\
\text { and solid wastes) }\end{array}$ \\
\hline $\begin{array}{l}\text { Ecological } \\
\text { stewardship }\end{array}$ & $\begin{array}{l}\text { Reduce } \\
\text { adverse } \\
\text { impacts } \\
\text { of } \\
\text { quarrying }\end{array}$ & $\begin{array}{l}\text { Potential KPIs: investments } \\
\text { in quarry } \\
\text { restoration, overburden } \\
\text { waste reduction, water } \\
\text { use efficiency, biodiversity } \\
\text { action plans etc }\end{array}$ \\
\hline $\begin{array}{l}\text { Employee } \\
\text { wellbeing }\end{array}$ & $\begin{array}{l}\text { Assure } \\
\text { worker } \\
\text { health and } \\
\text { safety }\end{array}$ & $\begin{array}{l}\text { Incident rate (injury, work- } \\
\text { related illness) per } \\
200,000 \text { hours (can include } \\
\text { both employees and } \\
\text { contractors) }\end{array}$ \\
\hline $\begin{array}{l}\text { Community } \\
\text { wellbeing }\end{array}$ & $\begin{array}{l}\text { Respect the } \\
\text { needs of } \\
\text { local } \\
\text { communiti } \\
\text { es }\end{array}$ & $\begin{array}{l}\text { Potential KPIs: frequency of } \\
\text { community } \\
\text { meetings, hours of volunteer } \\
\text { community } \\
\text { service, public health } \\
\text { initiatives, community } \\
\text { opinion surveys, etc }\end{array}$ \\
\hline $\begin{array}{l}\text { Regional } \\
\text { development }\end{array}$ & $\begin{array}{l}\text { Support } \\
\text { host region } \\
\text { economies }\end{array}$ & $\begin{array}{l}\text { Potential KPIs; job creation, } \\
\text { local investment, } \\
\text { technology transfer, } \\
\text { contribution to GDP, etc }\end{array}$ \\
\hline $\begin{array}{l}\text { Shareholder } \\
\text { value } \\
\text { creation }\end{array}$ & $\begin{array}{l}\text { Create } \\
\text { superior } \\
\text { value for } \\
\text { shareholder } \\
\mathrm{s}\end{array}$ & $\begin{array}{l}\text { Potential KPIs: return on } \\
\text { investment (ROI), } \\
\text { return on assets (ROA), } \\
\text { return on net assets } \\
\text { (RONA), return on capital } \\
\text { employed (ROCE), } \\
\quad \text { economic value added } \\
(E V A), \text { etc. }\end{array}$ \\
\hline
\end{tabular}

Action plan worldwide agreed by Association of Cementitious Material Producers (WACMP):
- WACMP members have committed to reducing $\mathrm{CO}_{2}$ emissions per ton of cementitious material and will correct subsequent analysis for trending action as substituting local waste material for blended cement and for concrete.

- Building and our policymakers have to undertake health management programs with particular attention to clean air especially from the dust given to our domestic and citizens' health.

\section{References:}

1. World Business Council for Sustainable Development, Towards a sustainable cement industry, Geneva: WBCSD, 2002.

2. World Business Council for Sustainable Development, Towards a sustainable cement industry Summary report, Geneva: WBCSD, 2002

3. World Business Council for Sustainable Development, The cement sustainability initiative: our agenda for action, Geneva: WBCSD, 2002.

4. J.Lukasik, J.S.Damtoft, D.Herfort, D.Sorrentino, E.M.Gartner, Sustainable Development and climate change initatives, Proceeding of XIIth ICCC, Montreal,

Canada, 2007, Vol 1. p23-32

5. K.Humphreys, M.Mahasenan, Toward a Sustainable Cement Industry. Climate change. An independent study commissioned to Batelle by World Business Council for Sustainable development, 2002

6. Impact of Europe's changing climate, European environment agency report no2/2004 